\title{
Investigating the Effect of Ownership Structure on Financial Performance of Listed Oil and Gas Firms in Nigeria
}

\author{
Esther Kwaya Daniel Umar Abbas Ibrahim, $\mathrm{PhD}$ \\ Department of Business Administration, University of Nile of Nigeria
}

\begin{abstract}
The study examined the effect of ownership structure on the financial performance of Nigerian listed oil and gas companies for the period of 2009-2019. The specific objectives of this study are to: Determine the impact of managerial ownership on the return on equity of Nigeria's publicly traded oil and gas companies. Analyze the effect of institutional ownership on the return on equity of Nigeria's publicly traded oil and gas companies. Examine the effect of ownership concentration on the return on equity of Nigeria's publicly traded oil and gas companies. Secondary data were used, which were extracted from the financial reports and accounts of the companies that comprised the study's sample. The study employed OLS as the best estimator of the regression model. One of the findings revealed Managerial ownership has a positive significant impact on the Return on Equity of oil and gas firms in Nigeria. The study recommends that, Managers should not be given the majority of shareholding in the ownership structure of the listed downstream oil and gas firms in Nigeria but rather they should be given a small portion of the shareholding of the listed oil and gas companies in Nigeria.
\end{abstract}

Keywords: Managerial Ownership, Institutional Ownership, Ownership Concentration, Firm Financial Performance.

DOI: $10.7176 / \mathrm{EJBM} / 13-12-05$

Publication date:June $30^{\text {th }} 2021$

\section{Introduction}

The global enhancement of economic relations and activities has made companies more professional which leads to the separation of ownership from management. The relationship between ownership arrangement and company financial success has long been discussed in finance literature. Mangers' and shareholders' interests are frequently at odds, resulting in issues that reduce both the value of the firm and the financial performance of the firm (Tatiana \& Stela, 2013). Shareholders are often known as corporate owners, whereas directors are agents or shareholders' representatives tasked with allocating company resources to maximize their moneyed (Benjamin, Love \& Kabiru 2014).

There are two ways to describe the relationship between managerial ownership and company financial efficiency. First, managers who hold shares in the firm would outperform non-manager shareholders who want personal gain without considering ownership concentration and mutual investors. Second, equity investment improves management productivity because it involves them in the day-to-day operations of the firm, and this presence improves the company's financial success.

The correlation between institutional ownership and business financial success is that institutional owners have a stronger ability to watch management due to the large number of shares they hold in the firm. Furthermore, major institutional owners have the opportunity, power, and capability to track, advise, and control managers. This institutional ownership of corporations will lead to management focusing more on organizational success and less on opportunistic or self-serving behavior (Edmans \& Manso 2010). Ownership concentration is also related to company financial performance because conventional theories have suggested that when a company's ownership is vested in the hands of a few sizeable shareholders, they have the ability to control the activities of managers through direct interference, thereby minimizing the agency's problems (Chen \& Swan, 2010).

Furthermore, ownership concentration has been shown in diversification strategy studies to in-crease a company's corporate diversification and efficiency because it is the biggest investment in a corporate company (Genc \& Angelo 2012). According to earlier research, different types of ownership structures have an impact on a company's financial performance. The report, on the other hand, focuses on whether the type of ownership structures has great impact on financial results of listed Oil and Gas companies in Nigeria, if such companies exist, and the levels of these influence..

\subsection{Statement of Problem}

Ownership structure is thought to influence company success as a tool for corporate governance to promote improved firm productivity. In Nigeria, most crises, inefficiencies, and the organizations' ultimate distress contribute to their ownership structure, to the division of power and to the management's suboptimal performance, resulting in a dispute with the owners. The primary reason for this is the rivalry between owners and the agent. Managers know the firm a lot better than shareholders, which makes it hard for shareholders to 
deter-mine if the company serves their interests (Ebehim et al, 2013)

Several studies have been conducted on the ownership arrangement and financial success of businesses. Some of the reports included Wang (2013) and Eric (2011). Harold and Belen (2015) did not find a statistically relevant association between the ownership structure and the firm financial performance.

Many research and related studies on ownership structure, focused on the capital structure of corporations, share valuation, corporate results and case studies, mostly based on the banking and insurance institutions of developed and emerging economies. On this basis, this article attempted to fill an existing void in the literature by focusing on the relationship between ownership structure characterized by managerial ownership, institutional ownership, and ownership concentration and financial results of listed Oil and Gas firms in Nigeria.

\subsection{Research Objectives}

The main objective was to investigate the effect of ownership structure on financial performance listed oil and gas companies in Nigeria. The specific objectives includes:

i. To ascertain the extent to which managerial ownership influence return on equity of Nigerian listed oil and gas companies.

ii. To determine the effect of institutional ownership on return on the equity of Nigerian listed oil and gas companies.

iii. To examine the impact of ownership concentration on return on the equity of Nigerian listed oil and gas companies.

\subsection{Research Questions}

Based on the objectives, the following questions are formulated:

i. To what extent does managerial ownership have an influence on return on equity of Nigerian listed oil and gas companies?

ii. What is the effect of institutional ownership on return on equity of Nigerian listed oil and gas companies?

iii. What is the impact of ownership concentration on return on equity of Nigerian listed oil and gas companies?

\subsection{Research Hypotheses}

In accordance with the objectives, three null hypotheses are proposed for the analysis, as seen below.

HO1: Managerial ownership has no significant influence on return on equity of Nigerian listed oil and gas companies

HO2: Institutional ownership has no significant effect on return on equity of Nigerian listed oil and gas companies

HO3: Ownership concentration has no significant impact on return on equity of Nigerian listed oil and gas companies.

\section{Literature Review}

\subsection{Concept of Ownership Structure}

According to Iwasaki (2017), ownership structure is characterized by the distribution of equity in terms of votes, resources, and shareholder identification. Eric (2011) classified ownership arrangement into two types: ownership concentration and ownership combination. While the former reflects the percentage of shares owned by most of the shareholder(s), the latter is equivalent to the name of the primary shareholders. In recent years, interest in ownership systems has been revived due to the increased complexities of corporate ownership portfolios. Ownership structure, as a framework for corporate governance to promote the firm's increased productivity, is believed to have affected firm results. For example, Adam Smith (1776) pointed out that jointstock firms are less productive than private copartner firms, since the directors will not watch over other people's resources with the same nervous diligence" as their own.

Demsetz and Lehn (1985) see ownership arrangement as the percentage of shares owned by a firm's most significant shareholders. To them, a firm's most significant shareholders are the five largest shareholders. Similar to Laiho et al (2014) is the definition offered by Ali-pour and Amjadi (2011) who posit that ownership structure is the make-up of the biggest five shareholders, which includes a combination of institutional, individual and managerial shareholders. Wang (2013) views ownership structure as the combination of three different groups of owners viz., insiders, control group and institutional shareholders.

Chen (2012) agrees that there are two widely used dimensions to the term "ownership structure": ownership concentration and owner identity. The divergence of voting and capital rights, according to Chen (2012), enables investors to gain control with little equity involvement through processes such as a double class equity and pyramiding, among others. 


\section{Managerial Ownership Structure}

Managerial ownership refers to a share or shareholding in a company owned by managers. Managerial ownership is not only intended to increase the wealth of the organization, but also to allow managers to match the interests of managers with those of the organization. Managerial ownership is calculated by the natural logarithm of shares owned by managers as shareholders of the company (Iwasaki, Mizobata, and Muravyev, 2017).

Institutional Ownership

Institutional ownership refers to a portion or shareholding of a corporation owned by major financial institutions, mutual fund, or endowments. Institutions generally purchase big volumes of outstanding shares of a firm and can have a significant influence on its management. Institutional shareholders are also typically professionals who generally use their experience to track management and ensure that their interests are aligned with those of the organization's interests. Institutional ownership is determined by the natural logarithm of equity owned by different institutions as investors in the company (Herciu, 2017).

Ownership Concentration

Ownership concentration, according to Shleifer and Vishny (2017), is a significant determinant of good corporate governance. It is believed that the greater the management's control of the company, the less the stakeholder disputes, and the lower the agency issue and expense associated with it (Eric, 2011; Fazlzadeh et al, 2011). Since insiders have an opportunity to defend shareholders' interests, they need less oversight from the board, which is an expensive monitoring option (Do et al, 2014).

Ownership concentration refers to a shareholding or shareholding in a company owned by shareholders with a majority interest or a substantial stake. The concentration of ownership gives the shareholders the incentive and the power to track and influence management decisions. Concentrated shareholders therefore take advantage of their large stake in reducing the disputes between management and the company by being more involved in controlling and protecting their assets. Ownership concentration is determined by the natural logarithm of equity owned by block holders as investors in the company.

\subsection{Concept of Firm Financial Performance}

Firm financial performance is viewed as a firm's financial viability, or the degree to which a business achieves its economic objectives. Research on firm performance can be traced to organization theory and strategic management (Hamid, 2011).

The principle of financial performance is a major topic in financial accounting, and it has taken on many forms in various dimensions. Maximizing earnings, increasing profits resulting from investments, and increasing shareholder profits are all aspects of financial performance assessment that are at the heart of a company's effectiveness. Richard (2009, Richard, Richard, Richard, Richard, Richard, Richard, Richard, Richard, Richard The term "performance" refers to three distinct aspects of a company's success: Financial results (profits, return on cash, return on investment, and so on), product market results (sales, market share, and so on), and shareholder returns (total shareholder return, economics value added, etc.).

Measuring Firm's Financial Performance

Measuring the financial performance of firms is one of the strategic management functions aimed at satisfying the interests of shareholders and other stakeholders in a company. The firm's performance assessment involves a periodic and systematic evaluation of its operations to determine the achievement of the firm's objectives.

Existing research on the relationship between ownership structure and financial performance" used different methods of measuring the financial performance of firms. Some studies measure the firm performance by accounting-based value or market-based or both methods of measuring the financial performance of the company. But the use of either of the two performance measures is bound by a peculiar bias (El-Maude, et. al., 2016).

Market measures are forward-looking and rely on market performance, while accounting measures represent historical aspects of company performance. Researchers also use accounting-based measures in addition to market-based measures (i.e. Return on equity, return on assets). Accounting, on the other hand, is the most widely used indicator of a company's success, with terms like 'return on assets' (ROA), 'return on equity' (ROE),'return on investment' (ROI), and Tobin's Q. In comparison to the yield on net assets, line elements such as gross operating revenue, operating income, or cash flow from operations may be included. This is because there is financial performance at different levels of the organization.

\subsection{Theoretical Framework}

This research adopts the Agency Theory because of its importance in the resolution of disputes that may occur between managers (agent) and shareholders (principal) of the firms, which also capture the relationship between the three forms of ownership structure (managerial, institutional ownership and ownership concentration ) of the research and the dependent variable. This conflict of interest can be overcome by promoting managers (agents) 
performance-based compensation programs, direct action by shareholders, the danger of being shot by owners, and the possibility of takeover, all the more so by fear of losing their investment in terms of shares held by them. In this theory, stockholders who are the owners or directors of the company employ agents to do the job. The principals assign the management of the company to the directors or managers who are shareholders' agents (Clarke, 2004).

\subsection{Empirical Studies}

The influence of the ownership structure on financial performance has been widely studied which led to interesting debate in the financial literature. For instance, in the investigation by Andreyeva and Dean (2014) assess the role of privatization, ownership structure and firm performance in the transition process of Ukraine, the authors use data from the Ukrainian Committee on Securities and Stock Exchange collected by the Harvard Institute of International Development (HIID). The 190 open joint stock companies in the study are selected from six sectors of the Ukrainian economy.: construction, machinery, metallurgy, food, transport and trade and services and excludes those from energy, oil and gas sectors to avoid problems associated with privatization of the largest industrial enterprises and monopolies. The study uses OLS to estimate the impact of labour productivity, privatization, concentrated insider ownership and concentrated outsider ownership on performance (annualized rate of growth of labour productivity). In line with previous findings, the study provides evidence that firm performance improves with ownership concentration.

Adekunle and Aghedo (2014) study the influence of corporate governance mechanisms on financial performance of 143 randomly selected firms quoted on the NSE as at December 31, 2011. The study which examines how proportion of outside directors, board size, CEO status and ownership concentration affect ROA and profit margin (PM), utilizes ordinary least squares as estimation technique. The findings support the monitoring role played by outside directors in reducing the agency problems of Nigerian listed firms. In line with the positive role of board size, the study indicates that firms with larger boards perform better than others. On the contrary, the coefficients of CEO status and concentrated ownership were not found significant in explaining variations in performance measured by ROA and PM. Drawing from these findings; the authors suggest the need for more outsiders on corporate boards of firms listed on the NSE and that the size of the board should be proportionate with corporate scale of activities.

Similarly, the study reports that higher leverage is accompanied by lower performance. In contrast however, the study provides sufficient evidence that larger and older firms with higher asset tangibility perform better than their counterparts. The study could not support non-linearity relationship between directors' portion of shares and ROE as the coefficients were insignificant. The lower Durbin Watson statistics of 0.863 reported by the study signals the presence of positive autocorrelation which may render the findings spurious. The authors recommend the diffused against the concentrated ownership structure as the latter is detrimental to return on shareholders' equity. Accordingly, regulatory authorities should emphasize the diffused as against block shareholdings when making policies.

\section{Methodology}

The study used Correlation research design. The correlation analysis design was considered adequate and appropriate for this review because it can clarify or define the statistical association between the study's dependent variable (Return on Equity) and independent variables (managerial ownership, institutional ownership, and ownership concentration). The study population is 11 Oil and Gas firms listed on the NSE as at December 2019 and covered a period of ten years (2009-2019).

Secondary documents were used to gather data for this study. To achieve the study's objectives, the data were sourced from the annual financial statement of the selected companies through the Nigeria Stock Exchange (NSE) Fact Book released in 2019.

\section{Method of Data Analysis}

The study used multiple regression analysis, which was used with application of Ordinary Least Square method. Multiple regression analysis is an extension of plain linear regression. It is used where the value of one variable must be predicted depending on the values of two or more other variables. The variable to be forecast is known as the dependent variable, and the variables used to forecast are known as the independent variables.

The Ordinary Least Squares (OLS) method used in this analysis is a parametric statistical calculation that is dependent on a set of assumptions, which could affect the validity of the test. The Pearson correlations have been used for inferential research. Two of the most frequently encountered issues in research such as this include the normal distribution of variables and the multicollinearity of independent variables using the statistical package for social science (SPSS 20.00). 


\section{Model specification}

The model below is used to test the null hypothesis that was developed for the analysis. The effect of P-values at $1 \%, 5 \%$, and $10 \%$ levels of importance is used to evaluate the null hypotheses. The first model is the functional model, which is the foundation for the second model of ordinary least squares (OLS), the firm performance model, was derived.

$\mathrm{ROE}=\mathrm{f}\left(\beta_{1} \mathrm{MANOWN}+\beta_{2} \mathrm{INSTOWN}+\beta_{3} \mathrm{OWNCON}\right)$

$\mathrm{ROE}=\alpha+\beta 1 \mathrm{MANOWN}+\beta 2 \mathrm{INSTOWN}+\beta 3 \mathrm{OWNCON}+\mathrm{FSIZE}+\mathrm{LEV}+\varepsilon_{\mathrm{i}}$

Where each of the variables is describe in the table below:

Table 1: Defining the Variables in the Model

\begin{tabular}{|c|c|l|}
\hline Variable & Specification & \multicolumn{1}{|c|}{ Measurement } \\
\hline Managerial ownership & MANOWN & $\begin{array}{l}\text { Percentage of shares owned by directors measured by Khalid and } \\
\text { Zahid (2012) }\end{array}$ \\
\hline Institutional ownership & INSTOWN & $\begin{array}{l}\text { The proportion of shares owned by directors is calculated by } \\
\text { Gordon and Edward's calculation of the proportion of shares } \\
\text { owned by institutional investors (2016) }\end{array}$ \\
\hline $\begin{array}{c}\text { Ownership } \\
\text { concentration }\end{array}$ & OWNCON & $\begin{array}{l}\text { Fazlzadeh et al. measured the percentage of shares held by } \\
\text { majority owners (2011) }\end{array}$ \\
\hline Firm size & FSIZE & $\begin{array}{l}\text { Bala, Darryl, and Matthew (2015) used the natural log of total } \\
\text { assets as a managed variable. }\end{array}$ \\
\hline Leverage & ROE & $\begin{array}{l}\text { Olokoyo (2012) used total liabilities / total assets as a control } \\
\text { variable. }\end{array}$ \\
\hline Return of Equity & Eric (2011) and Shah et al (2011) estimated net income after tax / \\
\hline A & Error term & \multicolumn{1}{|c|}{} \\
\hline Ei & &
\end{tabular}

Source: Field Survey, 2020

1. DATA ANALYSIS

This section presents the descriptive statistics and regression findings on the effect of ownership structure on financial performance of Nigerian listed oil and gas companies. The descriptive figures are shown in Table 2 below.

Table 2: The Correlation Between Managerial, Institutional Ownership, Ownership Concentration, Return on Equity.

$\begin{array}{lllll}\text { ROE MANOWN INSTOWN OWNCON LEV } & \text { FSIZE }\end{array}$

ROE

MANOWN .583 $.000^{* * *}$

INSTOWN $\quad .368$

$.019^{* *} \quad .189$

$\begin{array}{llll}\text { OWNCON } \quad .078 & 0.63 & .160\end{array}$

$\begin{array}{lll}633 & .697 & .323\end{array}$

$\begin{array}{llllll}\text { LEV } & .232 & .26 & -.276 & .416 & \\ & .150 & .103 & .085 & .008^{* * *} & \\ \text { FSIZE } & .487 & -.384 & -.214 & .273 & .139 \\ & .271 & .015^{* *} & .185 & .089^{*} & .393\end{array}$

The results from the table above shows that managerial ownership correlates positively with Return on Equity at $1 \%$ level of significance and institutional ownership correlates with the dependent variable (Return on Equity) at 5\% level of significance. Ownership concentration has no correlation with Return on Equity. Return 
on Equity correlates positively with ownership concentration at $1 \%$ level of significance and positive but not significant with managerial ownership and a negative correlation with institutional ownership. Return on Equity is significantly correlated with managerial ownership at 5\% level of significance and a negative correlation with institutional ownership but a positive and insignificant correlation with ownership concentration and leverage.

\section{Test of Hypotheses}

The table below shows the coefficient, T-value, P-Value, R, R2, Adjusted R2, F-stat., F-sig., and Durbin Watson of managerial, institutional ownership, ownership concentration and firm size.

Table 3: Ownership Structure and Financial Performance of Firms from OLS Regression Results

$\begin{array}{lll}\text { Variables } & \text { Coefficient. } \\ \text { Constant } & 0.915 & \\ \text { MOWN } & 3.154 & \\ \text { IN OWN } & 0.701 & \\ \text { OWCO } & -0.239 & \\ \text { LEV } & .430 & \\ \text { FSIZE } & 0.021 & 0.672 \\ \text { R } & & 0.452 \\ \text { R 2 } & & 0.372 \\ \text { Adj R2 } & & 5.611 \\ \text { F stat } & & 0.001 \\ \text { F-Sig } & & 2.734 \\ \text { DW } & & \end{array}$

The estimated equation from the analysis is as follows: $\mathrm{ROE}=0.253+0.135(\mathrm{MGOWN})+0.701$ $($ INOWN $)-0.239(\mathrm{OWCON})+0.430(\mathrm{LEV})+0.021($ FSIZE) When all other factors are set to zero, the financial output of companies as determined by Return on Equity equals 0.253.A transition in administrative ownership of a single unit while other variable are held constant will bring a corresponding positive change in return on equity of about $1.35 \%$. Holding every other variable constant, a unit change in institutional ownership will lead to a positive change of about $7.01 \%$ in return on equity.

Although ownership concentration, leverage and firm size have no significant impact on return on equity, holding all other variable constant, ownership concentration shows a negative impact of $2.39 \%$, leverage would have a positive impact on firm size would have a positive impact of $0.21 \%$ on return on equity respectively.

HO 1 : Managerial ownership has no discernible effect on the financial success of Nigeria's publicly traded oil and gas companies. The study's regression results reveal that the beta coefficient for managerial ownership is (0.478) and the t-value is (3.154). Managerial ownership has a major effect on Return on Equity at the $1 \%$ level of importance, implying that managerial ownership has a positive significant impact on the financial success of Nigerian listed oil and gas companies.

HO2: Institutional ownership had little discernible effect on the financial success of Nigeria's publicly traded oil and gas companies. In the case of institutional ownership, the beta coefficient is $(0.382)$, the $t$-value is (2.546), and the influence of institutional ownership on Return on Equity is substantial at the 5\% mark, meaning that institutional ownership has a favorable significant impact on the financial performance of Nigerian listed oil and gas firms.

HO$_{3}$ : Ownership concentration has no significant impact on financial performance of listed oil and gas firms in Nigeria. For ownership concentration, the beta coefficient is (0.239) and t-value is (0.946) and it is not significant as far as oil and gas firms are concern theoretically. The result of this is that concentrated ownership of Nigerian oil and gas companies has little major effect on the firms' financial results, which is contradicting the real life situation because while observing the individual firm annual report majority declared profit and among those firm declaring profit there exist major ownership concentrations

\section{Discussion of Findings / Interpretations}

Managerial ownership has a substantial positive impact on the Return on Equity of Nigeria's publicly traded oil 
and gas companies. This finding indicates that management of publicly listed oil and gas companies have a propensity for optimizing financial results and ensuring that the company's assets are adequately monitored and secured. Hu and Zhou (2006), Cheung, Fung, and Tsai (2008), Din and Javid (2011), and Ioraver and Wilson (2011) all support this conclusion (2011).

Institutional ownership has a positive significant impact on Return on Equity of listed oil and gas companies in Nigeria, suggesting that institutional shareholders track management and safeguard other shareholders' funds in the companies. The findings are consistent with those of Henry and Wang (2015), Zheng (2007), Per-Olof et al (2007), Jean and Hidaya (2010), Shohreh et al (2007), and Jean and Hidaya (2010). (2015).

Ownership concentration has no major effect on the Return on Equity of Nigerian listed oil and gas companies. The consequence of this is that, despite their huge funds, concentrated owners in Nigerian oil and gas firms have little effect on firm results, which contradicts realistic facts, which reveals that the role of concentrated owners improves financial performance of Nigerian oil and gas firms. This observation is consistent with the findings of Reuben and Narine (2004), Pinar et al. (2008), Ioraver and Wilson (2011), Kamran et al. (2012), and Lina et al. (2013).

\section{Conclusion}

This study concludes that managerial ownership has a major impact on the Return on Equity of the listed Nigerian oil and gas firms, implying that having more managerial owners in the oil and gas firms would improve the firms' financial efficiency. For example, the role of managerial owners in oil and gas companies demonstrates improved financial efficiency as shown by the high profit after tax recorded in their annual report. Institutional ownership has a direct impact on the Return on Equity of Nigerian listed oil and gas companies, indicating that the greater the number of institutional investors in the firms, the better the firms' financial results.

Ownership concentration has no impact on the Return on Equity of listed oil and gas companies, contradicting the fact that the role of concentrated owners improves the financial output of Nigerian oil and gas firms. This study believes that if a particular portion of shareholders have the power to overrule the decision of all other shareholders and managers opinion i.e. the opinion of the concentrated shareholders vote during decision making process is the ruling vote, the financial performance of listed oil and gas companies will invariably diminish in time to come.

\section{Recommendations}

In line with the findings, the study recommends that:

i. Managers should not be given the majority of shareholding in the ownership structure of the listed downstream oil and gas firms in Nigeria. But rather they should be given a small portion of the shareholding of the listed oil and gas firms in Nigeria, this will motive and encourage them to perform better in other to achieve the desired company goals and objectives as well as comply with the laid down guide lines of the companies which will increase their financial performance and their integrity.

ii. A particular group of individuals or companies should not be given the opportunity to hold the majority of the shareholding of listed downstream oil and gas firms in Nigeria. If in any way the ownership structure of listed oil and gas companies in Nigeria becomes one sided a lot of investors will have no option but to sell off their shares while prospective investors will not be convinced to come and invest their funds, this is because their opinions will never matter or make any difference since the ownership structure is one sided.

iii. Potential concentrated shareholders should invest in the oil and gas firms in Nigeria because in reality the presence of concentrated owners in the oil and gas industry enhances financial performance as opposed to the findings of the study.

\section{References}

Alipour, M. \& Amjadi, H. (2011), the effect of ownership structure on corporate perfor-mance of listed companies in tehran stock exchange: An empirical evidence of iran, International Journal of Business and Social Science Volume Number. 13.

Bala, R., Darryl, O. \& Mathew C.H. (2015), Firm Size, Ownership and Performance in the Malaysian Palm Oil Industry, Asian academy of Management Journal of Account-ing and finance, Volume number, 81-104.

Benjamin, K.G., Love, O.A. \& Kabiru, D. (2014), The Impact of Ownership Structure on the Financial Performance of Listed Insurance Firms in Nigeria, International Journal of Academic Research in Accounting, Finance and Management Sciences, Volume number 4, page number 409- 416.

Charfeddine, L. \& Abdelaziz, E. (2011), Institutional ownership and Firm Performance: Ev-idence from France, IUP Journal of Behavioural Finance, Volume number. 7, No. 4.

Chen \& Swan (2010), Institutional Trader Monitoring and Firm Performance; University of New South Wales, 
Wales. 63

Demiralp, I., Mello, R, Fedrick, P.S \& Venkat, S. (2011), Are there monitoring benefits to institutional ownership? Evidence from seasoned equity offerings.

Din, S. \& Javid, A. (2011), Impact of Managerial Ownership on Financial Policies and The Firm's Performance: Evidence Pakistani Manufacturing Firms, International Re-search Journal of Finance and Economics 14502887.

Do, X.Q. \& Wu, Z.X. (2014), The Impact of Ownership Structure and Capital Structure on Financial Performance of Vietnamese Firms, International Business Journal Re-search, Volume number 7, page number 2 .

Eric, E.M. (2011), Ownership Structure and Corporate Governance and Its Effects on Performance: A Case of Selected Banks in Kenya, International Journal of Business Administration Vol. 2, No. 3.

Edmans \& Manso (2010), Governance Through Trading and Intervention: A Theory of Multiple Blockholders, Wharton School, University of Pennsylvania. 64

Fazlzadeh, A., Hendi, T.A \& Kazeem, M. (2011), The Examination of the Effect of Ownership structure on Firm performance in Listed Firms of Tehran Stock Exchange, Vol. 6, and No.3.

Feng, L.L (2010), A Panel Threshold Model of Institutional Ownership and Firm Value in Taiwan, International Research Journal of Finance and Economics, 1450-2887. Friedman, M. (nd), Shareholder Theory.

Genc, A. \& Angelo, P. (2012), Ownership Concentration and Effects over Firm Performance: Evidences from Italy, European Scientific Journal, vol. 8, No.22 ISSN: 1857 - 7881, Italy.

Ghasemi, A. \& Zahediasl, S. (2012), Normality Tests for Statistical Analysis: A Guide for Non-Statisticians, International Journal of Endocrinology and Metabolism, doi: 10.5812.

Govert, V. \& Brain, T.M. (2010), Ownership Structure, Profit Maximization and Competitive Behaviour, IESE Business School, University of Navarra, Av. Pearson, 21-08034 Barcelona, Spain.

Hamid, A. (2011), Corporate Governance theories: Stewardship theory, Government linked Research Centre.

Laiho, T. (2011), Agency theory and ownership structure - Estimating the effect of Owner-ship structure on firm performance, Economics Master's thesis, Department of Economics, Aalto University,

Lina, M., Soud, M.A., Nimer, S. \& Alnimer, M. (2013), The Relationship between Owner-ship Concentration and Company Performance, A Case of Jordanian Non-Financial Listed Companies, Interdisciplinary Journal of Contemporary Research in Business, Vol. 4, No. 9.

Martin \& Adri (2010), Executive Compensation Contracts and Ownership Structure, Got-land University, SE62167 Visby, Sweden.

Nora, A.A. \& Anis, F.M. (2015), Ownership Structure and Bank Performance, Journal of Economics, Business and Management, volume number 3, page number 5.

Sahut, J.M \& Gharbi, O.H. (2010), Institutional Investors' Typology and Firm Performance: The Case of French Firms, International Journal of Business, 15(1) 1083-4346. 68

Sandal, A., Garba, T. \& Mikailu, S.U. (2011), Board Independence and Firm Financial Performance: Evidence from Nigeria, AERC Research Paper 213 African Economic Research Consortium, Nairobi.

Shah, A.Z.R., Butt, A.S \& Saeed, M.M. (2011), Ownership structure and performance of firms: Empirical Evidence from an emerging market, African Journal of Business Management Vol. 5(2), pp. 515-523.

Shohreh, H., Seyedeh F., Mir, R. \& Armin S. (2015), investigating the relationship between Institutional ownership with financial policies and Financial Performance of listed companies in Tehran Stock Exchange, Singaporean Journal Of Business Economics, And Management Studies Vol.3, No.11.

Tatiana, V. \& Stella, B. (2013), Ownership structure and Company performance: Research and Literature review, Financial Internet Quarterly, Volume 9.

Wahla, K., Shah, A.Z.S. \& Hussain, Z. (2012), Impact of Ownership structure on Firm Performance; Evidence from Non- Financial Listed Companies at Karachi Stock Ex-change, Euros Journals Publishers, 1450-2887.

Wang, W. (2015), Ownership structure and Firm performance; Evidence from Taiwan, Asia Pacific Management Review, National Kung University, 8(2), 135-160, Taiwan.

Waseem, A. \& Naila, T. (2011), Impact of Ownership Concentration on the operating Performance of Pakistani Firms, Asian Economic and Financial Review, 1(3), pp.147- 150. 